\title{
Music in construing cinematic emotions: intersemiotic aspect
}

\section{T. Krysanova}

\author{
Lesya Ukrainka Eastern European National University, Lutsk, Ukraine \\ Corresponding author. E-mail: tetianakrysanova@gmail.com
}

Paper received 01.02.19; Accepted for publication 06.02.19.

\begin{abstract}
The paper deals with the the role of music in construing negative emotions in English cinematic discourse in terms of its intersemiotic relationship with lingual and non-lingual semiotic systems. It is proved that the film music is characterized by the nonautonomous nature and is combined with means of other semiotic systems in order to construe negative emotions. Different types of film music - diegetic and non-diegetic, on-screen and off-screen that interact with other semiotic systems in the congruent or noncongruent way have been distinguished. The film music is capable of intensifying, specificating and contrasting the actualized film emotion.
\end{abstract}

Keywords: cinematic discourse, construing, emotion, film music, semiotic system.

Introduction. The study of the intersemiosis of emotions, which we interpret as a simultaneous multimodal construct of emotive meanings in polycoded discourses, requires the analysis of the peculiarities of construing emotions not only through the means of the cinematic lingual semiotic system, but also by means of non-lingual nature. The research of the negative emotions reveals their specific feature in the cinematic discourse - the strengthening of pragmatic influence through the aesthetization of communication, which is peculiar to multimodal and polycoded types of discourse. The polycoded character of the cinematic discourse consists in the use of lingual (verbal language), non-lingual (gestures, facial expression, prosody) and extralingual (the signs of the cinematographic nature - music, sound, lighting, camera movement etc) semiotic systems for the construing of emotive meaning, whereas the the multimodal nature of the cinematic discourse emphasizes its dynamic nature and reflects the orientation of the addressee through visual and audio modes.

Meaning-making in the cinematic discourse is the mental process of construing and ascribing emotion meaning to the cinematic sign based on the collective author's and recipient's inferential activity. The construing of meaning occurs at the intersection of semiotic systems, which determines the relevance of the study of the intersemiotic features of the cinematic discourse. Emotion is a complex psychological state, a mental event the experience of which "is entailed or instantiated by physical processes in the brain or body and thus can be explained by events in the physical world" [1]. Cinematic emotion is construed in the cinematic discourse through the interaction of lingual, non-lingual and extralingual means. Researchers $[5 ; 10]$ refer music to a cinematographic code, noting that music as a code or semiotic resource is a system of signs and rules of their combinations with each other, "a language of moods and emotions" [3, p. 93]. Music is one of the important sources of communication in cinema and a means of construing emotive meaning. Cinematic emotive meaning is created by a unique combination of music, images, verbal and non-verbal speech. With the help of "information" channels - visual and audio, the film translates meanings construed by combining semiotically heterogeneous codes.

A brief review of publications on the subject. The problem of the correlation of the music and emotions has been the subject of scientific discussions and research [2; $4 ; 5 ; 9 ; 11 ; 12]$. To some researches this correlation "appears to mean that the emotional character of music is a subjective commotion within the listener. To others the emotional character is an objective property of the music itself" [3, p. 93] The function of music in the film has changed its ontological structure in comparison with the forms of the existence of autonomous music. Music as "meaning" in film exists on three different levels: 1) as a pure musical code, referring to a certain type of music; 2) as a cultural musical code that elicits enculturated reactions; the music that plays while film's credits unroll and reveals the style and subject of the narrative; 3) as a cinematic musical code that refers to the film and bears specific formal relationships to coexistent elements in the film [5, p.185].

The film music is capable of construing film characters' emotions and causing viewers' emotions. "Music is codified by the filmic context itself, and assumes meaning by virture of its placement in the film" [4, p.3]. Emotions caused by music arise as a result of a complex interaction between music, viewer and the situation. [11, p. 7]. A. Cohen highlights the main aspects of the corelation of music and emotions, which is construed in a certain film episode: music controls the emotional response; emotions cause interest and music guides the viewers' interest to the necessary focus (event or hero); certain music stimulates the emergence of certain emotions; music makes a certain contribution to the sense of reality of the narrative, highlights important events; music creates emotional support of the situation; emotions generated by music are based on the experience of viewers [2, p. 264]. So, the music serves as a significant element in the process of construing emotions in the film due to its inherent expressiveness and ability to unite film events and viewers' experience.

Functionally, music is associated with the development of film events and the creation of a sense of reality. It provides formal and rhythmic integrity and continuity between shots; transmits narrative signals; establishes a specific mood and adds the expressive character, draws attention to on-screen events through structural and associative coherence; music integrates with the film and enables the symbolization of past and future events with the help of association in the human memory [2, p.258; 4, p.73]. Although music performs different functions in the 
film, giving referential and narrative cues and providing rhythmic continuity, but "first and foremost, it is a signifier of emotion itself" [4, p . 73]. The ability of music to construe emotions has been proved experimentally [3; 12], for instance, music is considered to be sad if it is minor in mode, slow in tempo, low in pitch and complex in harmony $[3,94]$. Music is strong in the representation of emotions and the screen is strong in the representing the object to which the emotion is directed [2, p.267].

The goal. The goal of the paper is to determine the role of music in construing negative emotions in English cinematic discourse in terms of its intersemiotic relationships with lingual and non-lingual semiotic systems. The goal of the article involves the following tasks: to highlight the types of music in the cinematic discourse; to analyze the nature of music in the cinematic discourse; to determine the types of intersemiotic connection of music with other semiotic systems in the process of construing negative emotions in the cinematic discourse.

Materials and methods. The material of the analysis in the article are episodes of actualizing the negative emotions of anger, disgust and sadness in films Music of the Heart and Groundhog Day. Music of the Heart, an American musical drama film (directed by Wes Craven), tells the story about violinist Roberta Guaspari who, having been deserted by her husband and feeling devastated, attempts to rebuild her life and reaches a great success in music teaching. Film music is represented by soundtracks "Music of My Heart" , "Turn the Page", "One Night with You", "Nothing Else" and is characterized with lyric melody, minor mode and smooth rhythm. Groundhog Day is an American comedy fantasy film (directed by Harold Ramis) that tells about Phil Connors, a TV weatherman, who, caught in a time loop, repeatedly relives the same day. The film music is characterized with high pitch, major mode and flowing rhythm. Anger, sadness and disgust belong to fundamental emotions [7], the universal basic property of humans, which is characterized by a combination of biological and social nature. Negative emotions play a mobilizing role, provide the rapid satisfaction of needs, serve as "emergency signals", indicating the disturbance of the balance [13, p. 155]. Basic emotions are today the main focus of scientific studies, they are assumed to be innate, reflex-like circuits that cause a distinct and recognizable behavioural and physiological pattern, therefore, they are typically the target of film music [9]. It is believed that variations in rhythm, tempo and melody express the emotional attitude and are able to enhance the verbal message $[3 ; 9 ; 12]$.

Accordingly, to study the peculiarities of construing negative emotions in the cinematic discourse, we use the methods of observing the speech material; semiotic analysis in order to reveal the interrelation between lingual, non-lingual and extralingual elements that serve to construe emotions in the English cinematic discourse; the method of intentional analysis of situations where negative emotions are actualized; the method of pragmalinguistic analysis of discourse. The film script texts employed for the analysis allow to determine the emotion type which the collective author plans to construe in the film and the way of its actualization.

Results and discussion The significant role of music in the cinematic discourse lies in its ability to construe meanings through the generation of emotions and act as a symbol of emotions. Viewers react not only to the imaginary emotions of film characters, but at the same time they react with their own feelings to the meanings that the film music creates. All feelings and emotions have their "psychological basis", that is, the mental complex on which they are based. The music-generated film characters' emotions must always be based on some experience: fear is the fear of something, anger and disgust are anger and disgust for something. When viewers hear the film music and interpret it as a sign of reflection of their emotions, they assume that emotions arise as a result of certain experience and memories. The music helps to construe emotions, revealing this experience, linking episodes, actions into one dynamic whole. Thus, the music construes emotions in the film through audio "information" channel and at the same time affects the emotional sphere of viewers.

Music, images and words in the film are inseparably unitied. Music deepens the emotional expressiveness of the image, comments on on-screen events, adding some meaning or clarifying them. The film music produces the sense of reality, created by words, influencing emotionally. Due to its expressiveness, the film music causes the associations with events, experiences or feelings, making a certain atmosphere and helps to realise the film metaphors, intensifying their meaning.

The film music is characterized by the dual direction: at the film events and viewers. According to this aspect, music manifests itself as a diegetic one - that relates to the imaginary world of a film, and a non-diegetic one, which refers to the real world of viewers.

Diegetic or on-screen music is intra-shot, it has a double form of existence - it sounds both in the real world of viewers and in the imaginary world of the film and it plays an important role in construing the meaning of the emotion, transmitted through events on the screen. In the episode of the film Music of the Heart, Roberta, who is experiencing a difficult life situation, finds the job as a music teacher and teaches children from poor families to play the violin. One of her students, Guadalupe, has the affliction through which she can not hold the violin firmly. Roberta, upset by the future divorce, enters the classroom and finds Guadalupe there, playing the violin awfully and feeling sadness due to her disability. On-screen music helps to emphasize the general depressive atmosphere of a hopeless situation for both heroines.

Guadalupe sits on a chair in the empty room, struggling to set up her violin. Roberta enters, surprised to see her.

ROBERTA Guadalupe? What are you doing here?

GUADALUPE I can't get the stop sign.

ROBERTA Honey, your teacher's probably looking for you.

Guadalupe sighs, then hands Roberta the violin.

GUADALUPE I can't come anymore. It's too hard.

ROBERTA The violin is hard for everyone.

GUADALUPE But everyone else is better than me. I'll always be slow.

Roberta looks at her sadly and puts the violin in its case [8].

Non-diegetic music is off-screen, it is directed only at viewers. It complements or contrasts with the emotive 
meaning construed by means of lingual or non-lingual semiotic systems, helping viewers to reconstrue it and performing the function of the emotional commentary. For example, in the episode when Brian, Roberta's close friend, comes to her room and they enjoy remembering their childhood at school. However, Roberta says sadly that she has already changed. The depressive atmosphere is emphasized by off-screen lyrical music, which lasts throughout the whole episode.

BRIAN Is this the same Roberta who got the orchestra to strike until they gave us new uniforms?

She laughs wistfully, then looks a little sad.

ROBERTA That Roberta's not around anymore [8].

In connection with its subjective character [4], that is realized through its ability to transmit different shades of meaning, the film music does not act as an individual means of construing emotions as verbal and nonverbal means can do. The film music provides the emotional support, a commentary that intensifies, complements or weakens the emotion, actualized by means of another semiotic system. Therefore, the music in the film is defined by its non-autonomous character, as it is always interconnected with the means belonging to other semiotic systems involved in construing the emotional meaning. The illustrative material shows that the film music can interact with the means

a) of the lingual semiotic system. In the episode when Brian angrily notes that Roberta fails to perform the role of a contractor in her house repair, his anger is actualized by a lexeme with a negative connotation "idiot". The lingual realization of anger is accompanied by "harsh", non-linier background music:

BRIAN You're an idiot! I told you -- you can't be your own contractor [8].

b) non-lingual semiotic system. In the episode of the film "Music of the Heart", the emotion of disgust is construed mimicly and accompanied by the diegetic music. The music performed by children badly is the cause of Roberta's negative emotion and at the same time it complements the emotion construed by mimic nonlingual means.

The kids play "Twinkle Twinkle Little Star" and they sound awful. Roberta looks disgusted as she leads them.

ROBERTA Slow bows! Slow bows! Don't squeeze! Stop! Everybody stop! [8].

c) lingual and non-lingual semiotic systems. In the next episode, the emotion of anger, which is actualized with the lexeme "horrible" and prosodic means, is accompanied and intensified by the music extra-lingual means.

Roberta's screaming at the kids as they play "Twinkle Twinkle Little Star."

ROBERTA First finger on the E! Three -- two -- one -open! (to a white girl with pigtails)Wrong string, Becky! We've done this fourteen times! And look at your nails! You're supposed to cut them for violin class! O.K, everybody stop! It sounds horrible! I can't believe how bad it sounds! [8].

The complex nature of the intersemiotic interaction of the film music with other semiotic systems of the cinematic discourse is determined by its multimodal and polycoded character. Semiotically-heterogeneous components which constitute the cinematic discourse create the common meaning and make one perceptual flow and their interaction serves the construing of the cinematic meaning.

The film music is capable of not only amplifying and refining the emotion, but also it can contrast with the emotion actualized by means of another semiotic system. Thus, the interaction of music with means of other semiotic systems occurs in a congruent or non-congruent way. Under condition of congruence, the film music simultaneously actualizes identical emotive meanings, completing or concretizing them. In the following example, Roberta's son, Nick, blaming his mother for failing to build relationships with Brian, feels anger towards her mother. The emotion is realized verbally with the help of the adjective"mean", negatively characterizing her personal trait and combined with the film music - a terrible guy's violin playing, which emphasizes the negative emotional atmosphere of the situation.

While Lexi sets up his violin, Nick opens his violin case, takes out the violin and angrily starts playing, loudly and roughly.

ROBERTA What the hell are you doing?

NICK The problem with you is you're mean to everybody and then they don't want to be with you! [8].

The non-convergence of the film music lies in the fact that the music and means of another semiotic system simultaneously actualize various emotional meanings, which gives additional expressiveness to the emotions and makes the influence on the viewer more effective. In the episode of the film Groundhog Day, the meaning of anger is actualized with non-lingual prosodic means that contrasts with the musical extra-lingual code, which contributes to the reduction of the intensity of anger and adds a positive tone to the conversation. As a result of the quarrel between Rita, Larry and Phil, Larry is angry with Rita and feels annoyed because of her disagreement. However, the intensity of anger decreases with the help of the lyrical song "I Can not Get Started With You", which sounds off-screen.

RITA There's something so familiar about this. Do you ever have deja vu?

Phil smiles. Then Larry enters.

LARRY (irate, to Rita) I don't believe it. Someone bought every distributor cap in this town. We're going to be stuck here all night.

Over Phil's sympathetic look we hear the song, "I Can't Get Started With You" [6].

Conclusions. Thus, the music in the cinematic discourse is characterized by realism and expressiveness, symbolism and emotionality, ambiguity and dual direction. The film music, belonging to the extra-lingual semiotic systeml plays an important role in construing the emotive meaning. Being inextricably linked with the image and speech, the film music is able to intensify or change the meaning of a shot, symbolizing its dynamics and conveying the inner experience of characters. Affecting the minds of the audience, the film music associates the film events with their emotional experience, which contributes to the reconstruing of the emotive meaning by the audience. The involvement of various types of the film music, diegetic or non-diegetic, onscreen or off-screen that interact with other semiotic systems in the congruent or non-congruent way allows film 
authors not only to create the emotional atmosphere of the film, but also send emotional signals to viewers in order to form an adequate emotional response. The film music through its affectivity combines the diegetic film world with the real world of viewers, participates in the construing of emotions and helps the viewers to adequately reconstrue it, immersing them into the imaginary world and enriching their emotional experience. The film music simultaneously symbolizes and provokes emotions, and emotions, in their turn, are the key to the inferencial process.

\section{REFERENCES}

1. Barrett, L. F, Mesquita, B., Ochsner, K. N, Gross, J. The experience of emotion // Annual Review of Psychology. $\begin{array}{lllll}2007 . & 58 & (1): & \text { P. } & 373-403 .\end{array}$ doi:10.1146/annurev.psych.58.110405.085709.

2. Cohen, A. Music as a source of emotion in film // In Patrik, N. Juslin \& John Sloboda (eds.). Handbook of Music and Emotion: Theory, Research, Applications. Oxford University Press. 2011. P.249-272.

3. Farnsworth, Paul R. 1969. The Social Psychology of Music. Ames, Iowa: The Iowa University Press.

4. Gorbman, Cl. Unheard Melodies: Narrative Film Music. Bloomington: Indiana University Press \& London BFI Publishing. 1987.

5. Gorbman, Cl. Narrative Film Music // Yale French Studies. No. 60.1980. P. 183-203. doi: 10.2307/2930011

6. Groundhog Day. Available https://www.imsdb.com/scripts/Groundhog-Day.html

7. Izard, C. E. The Psychology of Emotions. New York : Plenum. 1991
8. Music of the Heart. Available at: https://www.imsdb.com/scripts/Music-of-the-Heart.html

9. Kaminska, Z \& Woolf, J. Melodic Line and Emotion: Cooke'Theory Revised // Psychology of Music. 2000. P.131147.

10. Stam, R., Burgoyne, R. \& Flitterman-Lewis, S. New Vocabularies In Film Semiotics : Structuralism, PostStructuralism, And Beyond. London/New York : Routledge. 1992. $239 \mathrm{P}$.

11. Patrik, N. Sloboda, J. \& Sloboda, John. Music and Emotion: Theory and Research. New York: Oxford, University Press. 2001.

12. Peretz I. Towards a neurobiology of musical emotions // In Patrik, N., Sloboda Juslin \& Sloboda John. Handbook of Music and Emotion: Theory, Research, Applications. New York: Oxford University Press. 2011. P.99-126.

13. Tomkins, S. S. Affect as amplification: Some modifications in theory // Emotion: Theory, Research, and Experience. Vol. I. New York : Academic Press, 1980. P. 153-159. 